NBER WORKING PAPER SERIES

\title{
CRUMBLING PILIAR? DECLINING UNION DENSITY IN JAPAN
}

\author{
Richard B. Freeman \\ Marcus E. Rebick
}

Working Paper No. 2963

\author{
NATIONAL BUREAU OF ECONOMIC RESEARCH \\ 1050 Massachusetts Avenue \\ Cambridge, MA 02138 \\ May 1989
}

The authors acknowledge helpful comments from Kazuo Koike, John Taylor, Larry Katz, and seminar participants in Japan and the United States. Any errors or omissions are entirely our own. We are indebted to Naotake Kaibara, Yasunori Kakinuma, Takeo Naruse, Shoji Kaneko, Masatoshi Shibata, Takashi Izumi, Seigo Kojima, Iwao Fujiwara, Yoshinobu Kobayashi, Haruki Shimizu, and Osamu Nakabayashi for enriching our understanding of labor relations and union organizing in Japan. We would also like to express our gratitude to Kazuo Koike and Hiroki Sato for providing copies of their respective new books and other research materials. Financial support from the Social Sciences and Humanities Research Council of Canada, the Committee on Japanese Economic Studies, the Harvard Reischauer Institute and the National Bureau of Economic Research is also gratefully acknowledged. This paper is part of NBER's research program in Labor Studies. Any opinions expressed are those of the authors not those of the National Bureau of Economic Research. 
NBER Working Paper \#2963

May 1989

\section{CRUMBLING PILIAR? DECLINING UNION DENSITY IN JAPAN}

\section{ABSTRACT}

This paper seeks to understand the recent decline of union density in Japan from 358 in 1975 to $28 z$ in 1987 . The decline in density is analyzed in terms of the changing proportion of workers in high and low unionization groups and the changes in density within those groups. Then using a stockflow relationship we look at how the organizing rate of new unions affects the overall density. A regression model assesses our interpretation of changes in Japanese density.

Our principal findings are:

(1) Structural shifts in the composition of employment and of the demographics of the work force account for only a modest proportion of the drop in Japanese density. As in the United States, most changes in density occur within industries and among defined demographic groups of workers.

(2) Much of the decline in density is associated with the inability of Japanese unions to organize new establishments. We attribute this in part to lowered worker interest and stiffened management opposition to unionism following the oil shock, buttressed by unfavorable changes in the political and legal environment for collective bargaining and for union organization. and by other'management actions, such as creating additional pseudomanagerial posts for older male workers. 


\section{Combling Pillar? Declining Union Density in Japan}

Fran the mid 1970s through the 1980s, enterprise unionism, widely viewed along with lifetime employment and seniority wages and bonuses as one of the pillars of Japanese industrial relations, lost considerable ground in the Japanese labor market. Whereas in $197535 \%$ of Japanese workers were unionized (the vast majority in enterprise unions) in 1988 just 27 were unionized - a decline of over half a percentage point a year that places Japan second to the United states in "de-unionization" of the labor force. One Japanese goverrment agency has projected a union density of 148 in the year 2000 (Japan Ministry of Labor Policy Division 1987) while academics also foresee rates lower than $20 \%$ (Japan Institute of Labor 1986).

What explains the fall in union density in Japan? Is Japan headed for "ghetto unionism", where organized labor is limited to segments of the work force, as in the United States? What can be learned about the nature of enterprise unionism from the 1975-1980s Japanese experience?

This paper seeks to answer these questions. In section one we show that structural shifts in the camposition of employment, usually cited as the main cause of union problems in Japan, do not in fact account for the bulk of the decline in dersity. In section two we trace the decline largely to union failure to organize workers in new establishments and develop a model of the organizing process. In section three we apply the model to time series and cross-industry data on density and organization of new plants and find that the recuced growth of "economic rents" that followed the oil shock underlies mach of the union failure to organize new enterprises. We argue that enterprise unionism contributed to the decline by tying unions to firms' labor relations policy and limiting the incentive and resources for existing unions to organize emerging sectors. 


\section{The Decline in Japanese Union Density}

As a starting point for assessing the 1970s-1980s fall in Japanese density, we contrast the change in density in Japan with that in other OECD countries. Available international data (Freeman, 1988) shows markedly different country trends in unionization, with density falling sharply in the United states and Japan compared to most other developed countries ${ }^{1}$. The American loss of density resulted from massive de-unionization in the private sector, which dwarfed organization of the traditionally non-union public sector, and rectuced overall density to $17 \%$ of the work force in 1988 compared to a mid-1950s peak of $35 \%$. In Japan, the drop in density, which includes falling union representation in education and in the privatized railroad sector, began in the mid-1970s. ${ }^{2}$ The fall in Japanese and American densities has shifted the locus of unionism in the Western world to other countries. In 1970 the United States and Japan had $42 \%$ of all union members in the developed OECD countries (compared to 50\% of employees). In 1986 the two countries accounted for just $34 \%$ of OECD union membership (compared to $54 \%$ of employees) (Freeman, 1988). In the other large country with significant 1980s de-unionization, the United Kingdom, density rose in the 1970s, putting it on a different plane than the United States and Japan.

The divergence in densities among developed countries occurred despite generally similar shifts in employment toward service sector and white collar jobs and female and part-tine workers, belying structuralist interpretations of the fall in union density in Japan, or elsewhere. Even if mach of the drop in Japanese density were mechanically "attributable" to the changing composition of the workforce (in fact only a moderate proportion is so attributable), it would still be necessary to explain why these structural changes adversely impacted 
Japanese density but not, say, German, Canadian, or Australian density. The divergence in density between "countries with similar incustrial relations systems, such as the United States and Canada suggests, moreover, that seemingly modest differences in institutions may play a major role in determining the evolution of unionism in a country.

\section{Dissecting Declining Density}

Although the differing unionization experiences of OECD countries negates a pure structuralist interpretation of Japanese developments, knowledge of the degree to which the decline took the form of a falling proportion of jobs among highly unionized groups as opposed to falling unionization within groups is still useful in assessing potential causes of change. Aocordingly, we present in Exhibit I union densities by one-digit incustry in Japan for 1975 and 1986, and, for purposes of camparison, in the United States and Canada, as well. The Japanese and canadian data include public enterprises in the appropriate industry category rather than in government (this explains the relatively high service sector density rate in Canada) but the United States data do not. Different industry classifications notwithstanding, the exhibit shows that the difference between Japan or the United States and Canada resulted largely from differences within industries: density declined in Japan and in the United States in all industries save goverrment while falling modestly or holding steady in most industries in Canada. More disaggregate data for Japan confirm the picture of significant within-sector losses of density among two-digit industries (Japanese Ministry of Labor, Basic Survey of Labour Unions, 1975, 1986). Formally, when we use a shift-share analysis to decompose the change in Japanese union density into the part due to changes in the sectoral mix of employment (holding fixed base year sector densities); the part due to changes in within-sector densities 
(holding fixed the base year sectoral mix of employment); and their interaction, we find that less than one-fourth of the 1975-86 decline in density is attributable to the changing sectoral $\mathrm{mix}$ (line 1 of exhibit 2).

To see whether other structural changes in the camposition of employment account for the three-fourths of the drop che to within-inctustry changes, we performed further shift-share analyses of the gender, part-time/full-time, and temporary/regular worker $\mathrm{mix}$ of employment. To avoid double-counting shifts included in the incustry decomposition we "nested" calculations at later stages by counting only the contribution of changed characteristics of workers within the groupings of earlier stages. Different nested orderings (looking for instance at worker characteristics first and at the incustry effect last) yield different decompositions of the structural canponents of changes in density, as they allot interactions between changes in factors to the factor considered first, but give the same total structural effect ${ }^{3}$.

The first characteristic that we examined in this framework is gender. overall, the percentage of Japanese workers who are women rose by 4 points from 1975 to 1986. Given that $29 \%$ of Japanese women workers compared to $36 \%$ of male workers were unionized in 1975, the 4 point increase in the female share could have contributed at most 0.3 points to the decline in density $(=.04 \times(.36-.29))$ As much of the increased female employment was into low density service sectors, however, we have already included it in our industry computation; our nested decomposition attributes only 0.18 of the 4.58 within-industry decline in density to the increased female share of workers within industry (line 2).

The second worker characteristic that we examined is the percentage of temporary workers. The tendency for fims to increase the percentage of temporary employees to maintain flexibility has been cited as a cause of urion 
decline due to the likely low rate of unionization among temporary workers (Japan. Labor Problems Research Center 1988). As we have already allowed for the changing sex composition of employment within incustries, we look for changes in temporary employment within sex groups. Because the percentage of temporary employees is higher for females than for males and has risen for females but not for males, we focus on the increased percentage of temporary employees among women within inchustries. Unfortunately, we do not have data on their union density, so we make the extreme assumption that none are unionized. 4 Given this, we estimate that at most 0.4 points of the within incustry decline is due to the growth of temporary employment, which lowered the density of female workers within industries (line 3 of exhibit 2).

Third, we look at the effect on density of the growing number of regular employees who work part-time. Part-time enployees increased from $9.9 \%$ of all employees in 1975 to $11.7 \%$ in 1986. For males the rate fell fram $6.4 \%$ to $5.0 \%$ while for females it rose fram $17.4 \%$ to $22.7 \%$. In assessing the impact of these changes on unionization we again face a data problem, as the only available statistics on part-time workers by incustry include non-regular workers whose growth we have alreacy accounted for. To deal with this we assume that the increased use of part-timers is proportional to increased use of temporary employees in industries, and that no part-timers are unionized. The 1977 and 1985 Labor Force surveys indicate that 70\% (1977) and 80\% (1985) of the male parttimers and 57\% (1977) and 53\% (1985) of the female part-timers are regular employees. This suggests that the percentage of male employees who were part-time regular employees dropped fram 4.5 to 48 while the percentage of female employees who were part-tine regular employees rose from 9.9 to 12.08 . Among men, the proportion of temporaries showed no change, while female temporaries increased by 
4.4 points as a share of all female employees. By our assmptions, the decrease in male part-timers has essentially no effect on density. Among women, the growth in regular female part-timers is about 1/2 the growth in female temporaries so we assume that the contribution of part-timers is also half as large. This produces an estimated drop in density of 0.2 points (Iine 4 of exhibit 2) due to the decreased within-industry union density of women.

Summing the effect on density of changes in the camposition of employment by incustry, gender, temporary, and part-time groups, we estinate that about onethird of the 1975-1986 decline is associated with these structural changes. Since Japanese enterprise unions include white collar as well as blue collar workers, the remaining within-sector drop is unlikely to be significantly affected by the rising white collar share of employment - in contrast to the United States where the shift to white collar work has significantly reduced union density. Thus we conclude that the decline in density is due primarily to the loss of union representation arong orcanizable workers within sectors.

\section{Firm size and pseudo-management positions}

Two additional structural changes may have affected unionization in Japan: potential increases in the proportion of the workforce in small firms, which are less organized than large firms; and changes in the managerial proportion of the work force, particularly in large fins. To explore the first possibility, we estimated the proportion of employees in firms in different size groups and their unionization rates in 1977 and 1985, adjusting the relevant data for the movement of the Japan National Railways, Japan Telegraph and Telephone Public Corporation and the Japan Public Monopoly from public to private sector. ${ }^{5}$ Unadjusted data show an increase in density in large private sector firms, but this is misleading as it results from reclassification of the three privatized firms. our corrected 
figures (extibit 3) show substantial falls in density within all size categories, and no marked change in the distribution of firms by size. Hence, we reject firm size as an explanation of the drop of union density.

Management policies toward older male Japanese workers, whose share of employment rose substantially fram 1976 to 1986, has been suggested as another cause of decline in union density. To deal with the increased number of older male workers, who were too mumerous to be promoted to gemuine managerial slots, many companies created new "titular" and "specialist" posts, often with managerial titles that led workers to resign from their union, as Japanese law prohibits membership of individuals who "represent the interests of the employer". For example, formerly the position of section head represented the point at which a union member typically resigned, but in the 1980 s many workers in the newly created positions of "assistant section-head" or "assistant vicesection head" also gave up union membership. To estimate the impact of this change on union density, we looked at data on the percentage of non-union members within firms from a 1986 survey of 330 unions (Japan Labor Problems Research Center, 1988). The survey shows that smaller firms have a higher percentage of non-participants, possibly because they have larger supervisor/worker ratios and older workforces. Over half of the unions reported an increase in the number of non-union regular employees; one in twenty reported an increase of more than $5 \frac{5}{5}$ almost three quarters reported that sane non-member regular employees did not correspond to "management positions representing the interests of the employer"; and over half reported an increase in non-union members in management posts that do not represent the interests of the employer, with $8 \%$ estimating the increase to be over 5\%. On the basis of these figures we estimate that perhaps 1.1 percentage points in the decline of male union density in existing unionized 
firms between 1981 and 1986 could be che to aging and the proliferation of management posts. ${ }^{6}$ For males this could account for much of the within-industry decline in density in large firms, where union density is high, but not for the within-industry decline for all firms, where it is lower. For all firms, the 1981-1986 drop in density due to creation of pseudo-managerial posts within organized firms reduced density by about 0.3 points $(-0.3=$ the drop within organized firms $(-1.1 \%)$ times the union density (31\%)). If this change was as large from 1975 to 1981 as from 1981 to 1986, aging/creation of new management posts would have contributed -0.6 points to the 1975-1986 decline, adding an additional $10 \%$ to our decomposition (line 5). While significant, this still leaves much attributable to other factors.

\section{New Union Organization}

Since even the most generous structuralist interpretation of Japanese developments fails to acoount for the bulk of the fall in union density, and since density did not fall in countries with similar structural changes, one must go beyond structural factors to explain the crumbling pillar. In this section we present evidence that the key factor in the decline was union inability to organize new workplaces and present a model of the determinants of new organization.

\section{New unionization and density}

Changes in union density are best understood in the context of a stock-flow relation in which the changes depend on the organization of new workers relative to the size of the work force and the "natural" depreciation or appreciation of density due to the birth/death and contraction/expansion of organized and unorganized firms (Freeman, 1988). If UDENS(t) = union density in year $t$; $r=$ rate of loss in union membership due to declines in employment in organized 
workplaces ( $r$ is negative when menbership grows); $g=$ rate of growth of total employment; and PCINEW $(t)=$ ratio of workers who were organized fram t-1 to t to the work force in $t-1$, changes $(\Delta)$ in union density can be represented by:

(1) $\triangle \operatorname{UDENS}(t)=(-r-g) \operatorname{UDENS}(t-1)+(1-g) \operatorname{PCINEW}(t)$, which for constant $r, g$, and PCINEW, has steady-state density PCINEW/ $(r+g)$.

This equation directs attention to two determinants of changing density: the rate of organizing new workers (which could change as a result of structural shifts in the work force, decreased worker interest in unions, increased management opposition, recuced union organizing effort, etc.); and the "net depreciation" ( $r+g$ ) of density (which would change due to structural shifts, changed rates of plant-closing or of the contraction/expansion of union relative to non-union plants, and changed growth of employment in new non-union workplaces, etc.).

Exhibit 4 presents evidence that Japanese unions experienced a precipitous drop in their rate of new organization from the mid-1970s through the 1980s that roughly paralleled the drop in union density. Colum 1 shows that the number of Japanese workers joining newly formed unions fell fram an average of 184,000 in the mid-1960s-mid-1970s to 60,000 in 1986. Colum 2 shows that this decline reduced the ratio of workers in newly formed unions to the Japanese work force -the PCTNEW of our stock-flow equation - fran 0.50-0.70\% to $0.14 \%$. Data on the rate of new organization by disaggregated incustries show drops in nearly all incustries, so that changes in the industrial composition of employment explain little of the aggregate drop. 7

That the fall in PCINEW is a key element in the decline in density can be seen by simulating what would have happened to density from 1975 to 1985 if the rate of net depreciation had remained at its 1965-75 level while the rate of new 
organization followed its historic path. Between 1965 and 1974 density fell by I point despite a currulative rate of new organization of 5 points, which implies a net depreciation of $1.8 \%$ per year. ${ }^{8}$ Using the stock-flow difference equation (1) to simulate the levels of unions density that would have resulted from the observed levels of PCINEW at this depreciation rate, we obtain a drop in union density from $33.7 \%$ in 1974 to $30.0 \%$ in 1986, which amounts to 3.7 points, or nearly 2/3rds, of the observed 5.7 1974-1986 drop. The corresponding calculation for manufacturing shows a drop fram $39.8 \%$ in 1974 to $34.4 \%$ in 1986, explaining all of the 5.0 point drop.

Comparable figures on the muber of workers newly organized in the United States (colums 3 and 4 of extibit 4 ) show a similar pattern of a collapsing rate of new union organization that suggests a cammonality in the processes undermining union strength in the two countries. Where the United States and Japan do differ is in the net depreciation of density, which was on the order of 5\% per year in the United States from 1965 to 1975 (Freeman, 1988)--three times our estimated rate for Japan, possibly because of the greater growth of employment and turnover of jobs in America (a $25 \%$ rate of job turnover in the U.S. compared to a 7\% turnover rate in Japan - OECD, 1987). As in Japan, however, the fall in density is largely traceable to the drop in new organizing.

We conclude that changes in the rate at which unions organize new establishments - in the birth rate of unionism - underlies most of the decline in union density, and develop next a model of its determinants. Modeling new unionization

our model, shown schematically in Exhibit 5, assesses the role of economic conditions, legal institutions, management, and labor in union formation. It diverges from many models of unionization by stressing that management as well as 
labor affects union formation and by linking the behavior of both parties to the economic and legal enviroment. The model posits three basic relations:

1) A "profuction function" that relates the muber of workers newly organized relative to the work force to: the resources management devotes to opposing (favoring) unionization; the resources unions and workers spend on organizing; and a catch-all vector of other factors.

The production relation depends critically an the institutions governing new unionization - institutions that vary considerably among countries. In the case of Japan, although Japanese labor law was instituted during U.S. Occupation, the Japanese mode of organizing differs fram the American mode in several important ways. In Japan unions do not need majority support for certification nor are unions the exclusive bargaining representative of workers in a firm with a duty to fair representation for all. A small group of workers can organize a union, submit their union constitution and a list of members and elected officials to the Labor Relations Commission, an independent body with representatives from labor, business and govermment, and be officially certified. Registration with a Labor Relations Conmission is optional, however, and is often done only when there are complaints of unfair labor practices. ' The commission can certify more than one union in a workplace, and collective agreements are automatically extended to other workers only if a union makes up more than 3/4ths of the workers in a firm. As a result of these factors, organization of new unions is less confrantational than in the United States, where maragement and labor contest exclusive representation rights in secret ballot government sponsored elections that are often long and bitter (Freeman, 1985).

Although Japanese labor law nominally guarantees workers the right to establish unions irrespective of management, in practice management has an 
inportant role in union formation, as one might expect in a system where unions are enterprise based. Indeed, our interviews with union leaders in Japan suggest that much organizing is done by corvincing managers to accept the formation of a union at their work place. ${ }^{10}$

As in the United States an organizing drive usually begins with an attempt to form a mucleus of support around dissatisfied employees, almost always with the help of atside organizers. ${ }^{11}$ While during the early stages unions try to keep the drive secret from management, when they have the support of one-third or so of employees they will often approach management to ask for support or acquiesence to the unionization effort. The need to approach management without a clear majority seems to be due both to the difficulty of enlisting the marginally interested workers without such support and to the difficulty of maintaining secrecy as the campaign proceeds. All of the union leaders we interviewed agreed that obtaining management's approval (either by quiet persuasion or harassment and econamic threat) is critical to the success of the union. Marginally interested workers look to the authority of the company leader or senior management for guidance in choosing whether or not to support a union. If management accepts the union, organizers will often ask the campany president to address the workers on their behalf whereas if management is firmly opposed to the union, organizers will often have no option but to withdraw their organizing effort. In the cases where the union persists in its organizing efforts despite management resistance, it is likely to face significant managenent efforts to undermine support. Management will often encourage the formation of a second, more conciliatory union or, as a variant, create a "management-labor consultation committee" to develop channels for employees to use voice in the establishment without the accampanying disadvantages (for management) of genuine collective 
bargaining. Same $40 \%$ of unfair labor practices cases brought before the Labor Relations comission involve plural unionissn. Another tactic is to transfer union-organizing leaders from unorganized to organized firms or establishments within the same corporate grap.

That management opposition to new organization has the potential for significantly hindering the success of Japanese unions in organizing new enterprises is indicated by a 1986 survey of newly formed unions in the service sector (Tokyo City Labor Research Center, 1986). In nearly half of the cases, the union respondent reported that the employer had no knowledge of the organizing activity prior to the union's establishment, indicating that organizers feared opposition fram the management. In the $52 \%$ of the cases where employers discovered the organizing activity early, $43 \%$ of the unions reported attempts by management to breakup the drive, $27 \%$ reported attacks aimed at the organizing leaders and $25 \%$ reported discrimination against the pro-union employees. 12 As these were successful organizing efforts, it is reasonable to assume that an even larger percentage of all efforts to unionize met with comparable, or greater, opposition. While we came across no evidence that Japanese management undertakes massive U.S.-style union-avoidance campaigns, the enterprise union system gives management ample opportunities to influence worker assessments of the value of organizing in more subtle ways.

Turning to the posited impact of union organizing resources on the rate of new organization, perhaps the best Japanese example of how additional resources can increase membership is the experience of Zensen Damei (The Japan Textile Workers Federation) in the service sector, especially chain stores (Nakamura; Dore). In the 1970 s and 1980 s zensen structured its union leadership to concentrate on organizing; it hired over thirty regional organizers and enployed 
as regional chiefs professional organizers who rotate amang posts. As a result Zensen members in the distribution division have grown fram $5 \%$ of union membership in 1971 to $37 \%$ in 1987, allowing the union to increase membership despite declining textile employment.

2) The second relation in our model links management activities to deter unionism to econanic factors likely to affect the profitability of opposing an organizing drive: the potential loss of profits fram unionization resulting from the effect of unionism on costs through the union wage premium or other factors; the cost of actively opposing an organizing drive, which depends critically on the "technology" of resisting unions at work places, including the legal options for opposition, and penalties for unfair labor practices; the cost of establishing union-like work conditions (consultation committees, grievance procedures) that are likely to reduce worker interest in organising; and to the resources the union allocates to its organizing drive.

Contrary to the myth that Japan's enterprise-based unions are ineffectual, and thus unlikely to induce management opposition, evidence suggests that they have significant economic effects that ought to incuce at least some management resistance to organizing. In the area of compensation, Nakamura et al (1988) 13 present cross-section comparisons of union and nomunion workplaces showing that unionism: 1) raises the pay of female workers by 10-30\%, reducing male-female wage disparities; 2) raises bonuses and severance pay by 25-30\%; 3) raises severance pay for voluntary labor mobility relative to severance pay for involuntary mobility by same 10\%; and 4) reduces regular working hours per year, as workers use holidays and paid vacation days more in unionized than in nomuionized firms. They also report that two 1985 surveys of unions organized between 1977 and 1985 showing wage increases beyond what would have been expected 
in roughly half of the cases after unionization. In the area of work organization, Koike stresses the importance of "the union's interest and voice in a wide area of managerial affairs" (Koike, 1988, 252) while Nakamura et al note that upper limits on overtime are more rigidly observed for unionized firms and emphasize that unions limit the freedam of employers to lay-off or transfer their workers since all personnel changes must be made with same union consultation. In particular the tendency of Japanese firms to lay off more expensive senior workers (Koike 1988, 170-171) will meet with more opposition in a unionized setting. While we know of no study of the union inpact on profitability per se comparable to those in the United States (Freeman and Medoff, Salinger, Ruback and zimmerman), the evidence on what unions do in Japan suggests that, as in the U.S., they raise the workers' share of quasi-rents, potentially inducing at least some management opposition. The role of unions in opposing layoffs suggests that such opposition is likely to be more severe under adverse economic conditions.

3) The third relationship in the model links union (worker) organizing activity to: the wage premium and other benefits that unions bring to workers; existing union density; the resources managenent devotes to opposing unionism; and a catch-all vector of other relevant factors, largely relating to labor market conditions, such as labor market mobility, a factor often cited as an explanation for young workers' lowered interest in both firms and unions.

We make union organizing depend on existing union density for two reasons: because a high density spreads the cost of organizing new units over a larger number of existing nembers ${ }^{14}$; and because it increases the likel ihood that some existing unions will have an economic interest in organizing the unorganized. This should be especially inportant in an enterprise union system, where interest in extending unionization into new areas, such as the growing tertiary sector, 
may be small for enterprise-based organizations in other sectors.

Turning to the incentive workers have to unionize, the various campensation and nonompensation factors given earlier as costs to elployers (as well as factors that may berefit both sides, such as greater voice through joint consultation channels - Koike, 1988, p. 253) are likely to provide incentive to organize; and in fact surveys show that across age groups, firm size, education levels, and coapation graups the majority of unorganized workers in Japan have positive attitudes towards unions (Nakamura et al, 1988, p. 189).

Three aspects of our model deserve comment.

First, contrary to many analyses of union formation, our analysis posits that the union wage premium (other advantages to workers of organizing) has an ambiguous effect on organizing success. This is because higher wages/other benefits not only raise worker desires to unionize but also increase managenent resistance, with uncertain net effects. It is the magnitude of economic rents that has an unambiguous impact on unionisation: the smaller the rents the less likely will workers organise. If unions maintain a given premium when rents are small, management will spend greater resources opposing unions. If, by contrast, unions grant concessions/ accept smaller premiums when rents are small, worker interest in organizing will be less.

Second, the model posits interactions between labor's and management's allocation of resources to organizing. Management takes account of union organizing activity in its decision to oppose unions while unions take account of management resistance in its organizing activity, in both cases because what each side does affects the productivity of the others' sides resources. Because increased management opposition can lead unions/workers to forego organizing efforts by making the probability of successful collective bargaining small, the 
interactions imply that declines in union organizing activity or in professed worker interest in unionism should not be viewed as exogenous factors: they may, instead, be endogenous responses to changes in management resistance.

Third, the interaction of management and labor decisions and the dependence of union organizing on past density can produce amulative changes over time -persistent increases or decreases in unionism, as has cocurred historically in Japan, the United States, and elsewhere. Amulative changes cocar when organizing activity depends critically on density and/or when changes in the resources one side allots to organizing induce opposite changes in the other side, as described above.

Models of the type in exhibit 5 have been used to explain declining union density in the U.S. (Freman, 1988), where most analysts now regard intensified management opposition to organizing drives as a - if not the - major cause of union decline (Freeman and Medoff; Farber; Dickens and Leonard; Goldfield); and to explain the 1980s drop in union density in the U. K., where the Tory govermment's labor relations policies altered the benefit/cost calculus of organizing (Freeman and Pelletier, 1989).

Does this model also illuminate the decline in density in Japan?

We argue in the next section that it does - that much of the decline in Japanese unionism is due to increased management resistance to new unionism and reduced worker interest in unions, induced by a tougher econamic erviroment that reduced the econamic rents to be shared between the parties, and abetted by a more pro-employer legal erviroment.

\section{Economic Determinants of the Decline in. New Organization and Density}

As we lack direct measures of management resistance to unionism and of labor organizing activity, the evidence for our model is indirect. We show first that 
the timing of the decline in union density was roughly coincident with the tougher economic conditions that developed after the oil shock and was accompanied by court interpretation of labor laws more favorable to management and reduced worker interest in unions. We then present cross inctustry time series data that reveal that density and organizing sucoess fell most in sectors of the econamy with the greatest squeezes in profits per unit of capital or with the greatest deviation of quasi-rents per worker fan trend.

\section{Changes in economic and legal emvironment}

The image of Japan as a super-econamy notwithstanding, many Japanese firms experienced sufficient econamic pressures after the oil shock to make them potentially less conducive to unionization than in earlier years. Labor's share of the national output rose from $70 \%$ to $79 \%$ between 1971 and 1975 as a result of the massive wage increases that followed the oil shock, squeezing profits, and threatening hyper-inflation. A separate point of pressure on fins was their highly leveraged financial position. In 1972 the ratio of equity to total capitalization of principal corporate enterprises stood at $18 \%$ as compared with the U.S. level of $51 \%$ for all manufacturing and utilities. (Wallich and Wallich, 1976 p. 267). The slowdown in growth and increase in the price of raw materials brought many. small companies to nuin after the first oil shock. In 1977 the bankruptcy rate was $1.3 \%$ with 18,000 banknutcies in Japan and losses of $\$ 16$ billion - figures that appear to be larger than those in the United States (Saxonhouse, 1979). In ensuing years, the rise of the NICs and fluctuations in the exchange rate of the yen created additional economic problems for Japanese firms. Many firms in depressed industries art their workforce by calling for volunteers for early retirement, or through outright dismissal (Koike 1987, p.165-173). In the context of our model, the reduction in economic rents in the 
period can be expected to recuce union organizing sucoess, either by intensifying management resistance (if the union premium is stable) or by recucing worker interest in organizing (if union effects fall, as suggested by the reduced wage demands in the Shumto offensives after 1975).

Passibly independently or possibly as a response to the post-oil shock economic conditions, the legal erviroment in Japan also changed in ways that weakened the ability of unians to organize new workplaces. Court decisions made some union actions on the employer's premises or during working hours a violation of employers' property and management rights, effectively restricting organizers to off-premise activity atside of working hours. ${ }^{15}$ Even if the significance of these decisions is overstated by observers such as Kataoka (1984), they surely strengthened management's position in the organizing arena. In the public sector court decisions placed even greater limitations on union activity while the privatization of the three major public enterprises in the 1980 s eliminated thousands of jobs and created profit incentives for management to oppose unions (Japan Labor Bulletin, March 1 1987, p.6). The 1984-1986 drop in union density from $60 \%$ to $56 \%$ in the transportation, communication and utilities sectors shown in exhibit 1 is mainly attributable to this administrative reform.

\section{Econometric evidence}

To test the claim that post-oil shock econonic pressures on the Japanese econany contributed to the decline in union density, we have examined the time pattern of density fram 1965 to 1986 for the econamy as a whole and for 25 industries, linking density to lagged density, changes in employment, time trends or year dumy variables to reflect period effects and/or measures of economic pressures. Lagged density is included to reflect the impact of the past stock on current density; changes in employment is included because in Japan union workers 
are usually laid off last while non-regular workers and workers in small fins tend to be hardest hit in downtums, raising density when employment declines and because of the fact that when unions fail to organize new workplaces growth of employment rectuces density. Time trends (one for the total period and one for the post-1974 oil shock period)/year dumies are introduced to provide a tough "null hypothesis" against which our model can be tested.

Exhibit 6 summarizes the results of our analysis of the aggregate union density; in panel A we relate density to time trends, while in panel B we link it to an indicator of profitability, the ratio of profits to capital (= net worth). The panel A plots confinm our claim that the bulk of the drop in density occurred post the oil shock slowdown, with the post-1974 trend variable dominating the general trend variable. The near unit coefficient on the change in in ermployment in the underlying regression supports our claim that it is failure to organize new sectors rather than de-unionization of existing workplaces that underlies the loss of density as it implies an effective zero impact of employment growth on new union membership. The panel B regressions show that our measure of profits/ capital, which dropped considerably during the post-oil shock period, does just about as good a job explaining the pattern of density as the trends. If we include trends and our profitability measure in the same equation, both enter significantly, but the bulk of the decline is captured by the trend variables, ${ }^{16}$ as might be expected given the smooth post 1974 decline in density illustrated in the exhibit.

To make a firmer assessment of the economic deteminants of the decline in Japanese union density than is possible with limited time series data, we developed a cross industry/time-series data set linking union density and organising success to measures of profitability or quasi-rents. This data set 
contains upwards of 420 observations for 6 one-digit and 19 two-digit

manufacturing industries with sufficient cross-section and time-series variation in density, organizing success, and econcmic conditions to provide a strong test of our model. We estimate one equation for the change in In density:

(2) $\Delta$ in DENSITY $=a+b \Delta$ In DEMP $+c P+d$ In DENSTTY $(-1)$ and one for the level of organizing activity:

(3) In PCINEW $=a+b P+c$ In DENSITY $(-1)$, where in is the natural logarithm; EMP is employment; and $P$ is our measure of economic pressure.

Exhibit 7 presents the results of our cross-section time-series analysis of changes in density (columns 1-3) and of organising success (columns 4-6) in 2 digit manufacturing and 1 digit non-manufacturing industries grouped together. The key variable is the in ratio of profits to net worth in each industry, which our analysis predicts should be inversely related to changes in unionisation. ${ }^{17}$ In columns 1 and 4 this variable is entered with the change in employment and lagged density but with no trend variables. Since the regressions include industry dunmy variables the coefficients on profitability provide the input needed to estimate the effect of within-industry profit-squeezes on changes in density/ organizing success. Columns 2 and 5 record coefficients from regressions in which we added a time trend and a post-1974 time trend, while columns 3 and 6 record the results of regressions with indivichal year cummies.

There are four findings in the table. First, in all of the calculations for the change in density, including those with the two trend variables and those with the year chumry variables, our profitability measure dbtains a positive coefficient, indicating that a profitable econamic erviroment is conducive to unionization while a less profitable one is not. Second, as in the aggregate analyses, employment changes have an adverse impact on density. Third, the 
colunn 4-6 regressions, which look behind the changes in density to the determinants of the rate of organizing new worker, yield substantial statistically significant effects for profitability that indicate that it affects density by altering organizing sucoess, as posited in our model. Fourth, lagged density, which plays an important role in our model because it incuces cumulative changes over time, abtains positive coefficients in all cases, with an exceptionally large coefficient in the regressions lacking trend terms.

on the basis of the regression estimates in exhibit 7, how much have withinindustry changes in profitability contributed to the aggregate drop in density, compared, say, to the other factors considered earlier in exhibit 2? To answer this question, we have used the colunn 1 model to derive the longterm impact of profitability on the equilibrium level of dersity (=coefficient on profitability) coefficient on the lagged density term) and mitiplied it by the 1975-86 change in our profitability measure. our resultant estimate is 5.2 In points of in density, or about 2 points of the 6 point drop in density. As indicated by the smaller coefficients on profitability in colunns 2 and 3, when trend terms are included, changes in profitability add mach less explanatory power - about 1 point in the change in density.

Because any indicator of profitability is subject to problems of measurement and definition, we supplemented the exhibit 7 analysis by examining the impact of a second measure of profitability on changes in density and on the rate of organizing sucocess: "quasi-rents" per worker in manufacturing, where we have sufficiently good data to estimate quasi-rents per worker as value added minus compensation/ employment. ${ }^{18}$ since increases in the capital stock necessarily raise quasi rents per worker, we concentrate in this analysis on deviations in quasi-rents from trend, regressing changes in union density or rates of 
organizing success on quasi-rents/employee, trend variables/year dumies, and the other variables fram our model. Exhibit 8 presents the results of these calculations and, in columns 1 and 4, of comparable calculations using our previous in profits/capital measure of profitability. With trend included, the quasi-rent per worker variable (obtained, as noted in the exhibit, from a completely different data set than that for profits/asset) obtains the hypothesized positive impact on changes in density and an union organizing success, with a statistical significance comparable to that for our original profitability measure.

\section{Interpretation}

While the available data and interactive nature of our model makes it difficult to distinguish the separate role of enhanced management resistance to unionization and reduced worker interest in organizing, the computations lend considerable support to the notion that the underlying exogenous cause of the fall in density was the change in econamic conditions that followed the oil shock. ${ }^{19}$ Consistent with our stress on the impact of profitability, a 1986 survey of labor union activity reports that $43 \%$ of unions in firms in which within-firm density fell cited falling profits as a major influence on union organizing compared to only $30 \%$ in firms with steacy or rising within-firm density (Survey of Labor Union Activity 1986, p. 52). Similarly, surveys of employee attitudes in Japan show a roughly coincident drop in worker interest in unions, especially among younger workers. An NHK survey reports a drop in the percentage of workers who said they would try to form a union if they were dissatisfied with working conditions in their company fram $32 \%$ in 1973 to $25 \%$ in 1983, with most of the drop occurring after 1978 and among younger age groups (Japan Ministry of Labor Policy Division 1986). A separate survey of young 
employees (Japan Productivity Center 1988) shows that the percentage of labor force entrants who feel that labor unions are good for the workplace dropped from $84 \%$ in 1973 to $63 \%$ in 1988 , with 7 points of this drop cocurring between 1973 and 1975 and 8 points between 1985 and 1988 - both periods in which the world econamy changed in ways that adversely affected profitability and thus by our analysis were likely to have rectuced worker interest in organizing. As an alternative hypothesis, we also looked at the possibility that increases in union dues could be reducing worker interest in unions. While union dues rose from 1.5\% of wages in 1975 to $1.8 \%$ in 1979, they fell to $1.7 \%$ in 1983 (Ohara Institute, p.197) - a pattern of change that does not seem consistent or large enough to explain the attitude changes.

All told, the mid-1970s/1980s decline in Japanese union density, like the decline in U.S. and U.K. densities, illustrates the vulnerability of decentralized unionism to adverse economic circumstances and reveals the primary weakness of enterprise unionism: the difficulty of organizing workers across firm and, by extension, sectoral lines when econamic conditions make firms less willing to accept organization of their workers, and workers less interested in devoted effort to organizing in the face of management reluctance to accept unions. 
1. In same cantries density was roughly stable (Cermany, Carada, Australia); in others it increased (Scandinavian countries and Belgium); while in others it increased in the 1970 s but fell in the 1980 s (Italy, United Kingdam, France).

2. If we consider union membership as a share of the total workforce (including agriculture), then the drop since 1975 is smaller, from about 24 to $21 \%$ (28 to $23 \%$ for nonagricultural employment). Also, the rate of coverage of by collective agreements has risen fram 808 in the mid-60s to 908 by 1975. If we consider the density of covered union members, then the rate rises between 1965 and 1975, and falls by 5.4 points ( $90 \%$ of 6 points) thereafter. Note also that 1975-1987 is not the only time when union density fell sharply in Japan. In 1938 the military govenment replaced unions, which had organized upwards of $7 \%$ of the industrial workforce, with patriotic associations; and in 1940 dissolved the Sodomei federation, effectively terminating the pre-war labor movement. (Garon) In 195051 the unions established under the American Documation of Japan, which achieved a peak density of 568 in 1949, suffered major losses when the cocupation authorities and the Liberal Party cabinet of Yoshida Shigeru, sought to reduce union strength following major labor turbulence, first by revising probibitions against the formation of businessmen's associations, denying the right to strike for public employees, and tightening union certification procectures, then by encouraging the dismissal of thousands of alleged canmunists in both the public and private sector. During the "Red Purge", union density fell to $42 \%$ in 1951 . slow growth of union members due in part to rationalization of the workforce in mining and manufacturing brought union density down to $32 \%$ by 1960 . The industrialization of the 1960 s saw a rise in density to $35 \%$, a level which held roughly steady until 1975 when the decline on which we focus began.

3. To see this, take a simple case of two factors.

Let $s_{w}, s_{m}$ be shares of women, men in the labor force.u and $u_{m}$ are the unionizatiun rates.

Then $U=s_{w} \cdot u_{w}+s_{m} \cdot u_{m}$

A. $u_{w}-\sum u_{i w} \cdot s_{i w}$ where $u_{i w}$ is the unionization race for women in industry $i ; s_{i w}$ is the share of women fn industry $i$ in the total female labor force.

B. $s_{w}-\left(s_{w i} \cdot s_{i}\right) / s_{i w}$ for all $i$, where $s_{w i}$ is the share of women in industry i.

$$
\begin{aligned}
& \text { Then } U-\Sigma s_{\text {wi }} \cdot s_{i} \cdot u_{i w}+s_{\text {mi }} \cdot s_{i} \cdot u_{i m} \\
& \Delta U-\Sigma\left(\Delta s_{w i} \cdot s_{i} \cdot u_{i w}+s_{w i} \cdot \Delta s_{i} \cdot u_{i w}+s_{w i} \cdot s_{i} \cdot \Delta u_{i w}\right)+ \\
& \Sigma\left(\Delta s_{m i} \cdot s_{i} \cdot u_{i m}+s_{m i} \cdot \Delta s_{i} \cdot u_{i m}+s_{m i} \cdot s_{i} \cdot \Delta u_{i w}\right)+ \\
& \text { second and third order Interaction terms which we } \\
& \text { discard. (See below). }
\end{aligned}
$$


Now, the third cerm inside the brackets for both summations reflects changes in the base unionization rates. Since this is not a structural change we ignore this term.

Then using the fact that $\Delta s_{w i}--\Delta s_{m i}$ and the fact that

$$
\begin{aligned}
& s_{w i} \cdot u_{i w}+s_{m i} \cdot u_{i w}=u_{i} \text {, it follows that } \\
& \Delta U=\Sigma \Delta s_{w i} \cdot s_{i} \cdot\left(u_{i w}-u_{i m}\right)+\Sigma \Delta s_{i} \cdot u_{i}
\end{aligned}
$$

Now, the second term in this expression is the sex factor's contribution to the changes in industry share. We have already considered the contribution of this part of structural change during the shift-share analys is of industry. Then it is the first term which reflects the yet uncounted contribution of the sex factor to structural change in $U$. Our calculation of this term gives us the nested contribution of the sex factor.

The second and third order terms which we have ignored should be small individually, and will only be significant if they are all of the same sign. We believe this is unlikely for two reasons. Fir.t, the interaction effect in the industry shift-share analysis was negligible. Second, we calculate the rested effects for two subperiods of the total period 75-86. The sum of the effects in the two subperiods is very nearly equal to the effect over the whole period, even though the base unionization rates used for the two sub-periods are different, and the industry shares are different in both periods.

The result given above can be extended inductively to any number of sub-factors.

4. That this not that extreme an assumption is indicated by the fact that just $11 \%$ of temporary employees join unions if there is a union in their firm (Japan Ministry of Labor, 1986). If one-third of workers are unionized, then the unionization rate of temporary workers would be abort $4 \%$.

5. The Labor Force Survey places enployees of the public enterprises in its enterprise size category for enterprises with over 1000 enployees. The Labor Union Survey places these workers in the public sector category within each industry. Using data from the Ministry of Finance reported in the Japan Statistical Yearbook, we have shifted the public enterprise enployees over to the public sector category in the Labor Force Survey to correct this discrepancy. This avoids an artificial boost in the density of the 1000+ firm size category when these public corporations are privatized. We also leave these enterprises in the public sector in 1985, after two of then were privatized to control for an 
artificial increase in weight being given to the larger firms.

6. our estimate is abtained by multiplying the of of fins with non-members who are not enployer's representatives) by ( $t$ of firms showing an increase over the last five years) and by (average increase over the last five years for firms that have had increases). This gives $73 \%$ X $50 \%$ X $3 \%=1.1 \%$

7. Specifically, we have the following:

$\begin{array}{lcc}\quad \text { Incustry } & \text { PCINEW, 1974 } & \text { PCINEW, } 1986 \\ \text { Manufacturing } & .69 \% & .18 \% \\ \text { Construction } & .23 & .06 \\ \text { Services } & .55 & .13 \\ \text { Trade } & .39 & .10 \\ \text { Transp., Commun., Utilities } & .72 & .22\end{array}$

8. We abtain these estimates by using the stock-flow equation: over the period considered union density dropped from $35.0 \%$ to $34.2 \%$; the newly organized worker to employee ratio amallated to 5.5 percentage points. Using the stock-flow formula, we divide the difference between -0.8 and $5.5(=-6.3)$ by the $35.0 \%$ initial density to obtain the estimated rate of depreciation.

9. From 1973 to 1981, $61 \%$ of new certification applications were brought to the commissions as a result of unfair labor practices. (Central Labor commission)

10. The interviews were conducted January 10-13, 1989 with Zensen Damei (Japan Federation of Textile, Gament, Chemical, Nercantile and Allied Inchustry Workers' Unions), Jidosha-Soren (Confederation of Japan Autamobile Workers'

Unions), Kinzoka Rokyo (MMF-JC - Japan Council of the International Metalworkers Federation), Denki Roren (Japan Federation of Electrical Workers' Unions), JPTUCRENGO (Japanese Private Sector Trade Union Conference), and Nikkeiren (The Japan Federation of Employers Association)

11. A survey of unions formed between 1977 and 1983 reveals that over $90 \%$ of unionization drives relied on the help of an outside organizations, with $62 \%$ receiving help from union federations; $18 \%$ unions from parent firms or other firms in the same industry; and $23 \%$ receiving aid from unions outside the incustry aid the drive. Nakamura et al, p.197-200

12. Nakamura(1988) p. 199. The last results mentioned are fram a multiple response question. (25\% response rate on a mailed questionnaire to 500 new tertiary sector unions.) The same survey also reports that roughly $1 / 3$ of the unions reported that management showed a hostile attitude towards the new union and its membership. (Ibid, p.73)

13. Most Japanese govenment surveys of workers or establishments do not include questions concerning unions. As a result, the ability to do even a simple crosssection stuxdy of union wage effects is limited. Nakamura et al (1988, pp. 24-46) use evidence fram a series of mail surveys conducted by the Tokyo Labor Economics center. In particular they focus on a survey of small- to medium-sized manufacturing enterprises in Tokyo conducted in 1982. Of the 1874 firms who received questionnaires, 362 unionized and 272 non-unionized firms responded. (Large firms are excluded since the unionization rate is virtually 100\%.) There were also follow-up interviews of same 1800 personnel at 134 firms. One extreme limitation of this study is that firm size is the only control variable used. The sub-industry sample sizes are too small to use industry controls. Another possible limitation is the overrepresentation of the publishing and printing 
incustry, which makes up roughly $1 / 3$ of the sample of unionized firms.

14. This follows fram the algebra. If it oosts $x$ yen for an existing union to organize a norumion worker, then the cost of organizing a given percentage of the work force for each current union member is just $x$ (1 - UDENS) / UDENS.

15. The Hotel Okura case of 1975, the Kofu Railway Motive Power Union Billpasting case of 1975 and the Japan Air Lines case of 1976 are exallples of regional court judicial precedents that favored the rights of employers (private and public) over those of workers in this fashion. The supreme court handed down. a similar decision against the Sapporo Branch of the National Railway Workers Union during 1979. While unions can carry on activities autside of woriking hours and off-premises, enterprise-based unians tend to restrict themselves to activities at workplaces where they have use of firm facilities and are able to enlist the help of marginally interested workers.

16. The regression with profits/capital and the time trends is:

$\Delta$ In DENS $=-.3 \quad-1.1 \Delta$ in EMP +.04 ln PROF/CAP -.4 ln DENS $(-1)-.005 t-.001 \quad t$ (.1) (.2) (.02) (.1)

$(.001)(.003) \quad 74$ where DENS is union density, EMP is employees, PROF is operating profits, CAP is total assets, and $t$ and $t$ are the two time trends.

17. We have not adjusted reported profits for the impact of unions on wages, and thus do not have a true measure of quasi-rents. Using reported profits rather than estimated quasi-rents is likely to work against our analysis, as sectors where union effects are greatest will report lower profits even when quasi-rents may be high.

18. Once again, we have not taken account of the impact of unionism on wages in our estimate of quasi-rents and thus bias our analysis against the model.

19. Nakamura et al, pp.9-10 refer to the work of Sano and ono showing that union density and the density of collective agreements are highly significant in explaining interincustry wage differentials curing the 1960's. If this effect has declined over time, this would tend to support the worker discouragement side of our model. 
EXHIBIT 1:

Changes in Union Density by Sector: U.S., Canada and Japan

\begin{tabular}{|c|c|c|c|c|c|c|c|c|c|}
\hline \multirow{3}{*}{ Total } & \multicolumn{3}{|c|}{ United States } & \multicolumn{3}{|c|}{ Cañada } & \multicolumn{3}{|c|}{ Japan } \\
\hline & $1973 / 5$ & 1986 & $\Delta$ & 1975 & 1984 & $\Delta$ & 1975 & 1986 & $\Delta$ \\
\hline & 29 & 18 & -11 & 35 & 37 & 2 & 34 & 28 & -6 \\
\hline Manufacturing & 37 & 24 & -13 & 49 & 45 & -4 & 40 & 35 & -5 \\
\hline Construction & 38 & 22 & -16 & 63 & 39 & -24 & 18 & 19 & 1 \\
\hline $\begin{array}{l}\text { Transportation } \\
\text { Communication } \\
\& \text { Utilities }\end{array}$ & , & 35 & -15 & 56 & 60 & 4 & 66 & 56 & -10 \\
\hline Service & 7 & 6 & -1 & 15 & 36 & 21 & 26 & 19 & -7 \\
\hline Mining & 35 & 18 & .17 & 47 & 33 & -14 & 41 & 43 & 2 \\
\hline Trade & 11 & 7 & -4 & 9 & 13 & 4 & 11 & 11 & 0 \\
\hline $\begin{array}{l}\text { Finance, } \\
\text { Insurance \& } \\
\text { Real Estate }\end{array}$ & 4 & 3 & 1 & 1 & 9 & 8 & 20 & 18 & -2 \\
\hline Government & 24 & 36 & 12 & 73 & 67 & -6 & 67 & 69 & 2 \\
\hline
\end{tabular}

SOURCE: U.S. 1973/5: Richard B. Freeman and James Medoff, "New Estimates of Private Sector Unionism in United States", Industrial and Labor Relations Review, $32: 2$, January 1979 .

Canada: W.D. Wood and Pradeep Kumar, "The Current Industrial Relations Scene in Canada: 1977 and 1986" (Queens Univ, Kingston, Canada)

Japan: Basic Survey on Trade Unions, Japan Ministry of Labor

Labor Force Survey, Prime Minister's Office

The Japan National Railroad and Japan Telephone and Telegraph Public Corporation are included in Transportation, Communications and Utilities in 1975 


\section{EXIIBIT 2}

Estimated Impact of Structural Changes on Union Density: 1975-86

STRUCTURAL FACTOR

$\underline{1975-1986} \underline{1975-1981 \quad 1981-1986}$

TOTAL CHANGE IN DENSITY $\quad-6.1 \quad-3.6 \quad-2.6$

1. Industry

$-1.4$

$-1.0 \quad-0.4$

2. Sex

$-0.1$

$-0.1$

0.0

3. Temporary

$-0.4$

$-0.3$

$-0.1$

4. Part-time

$-0.2$

$-0.1$

$-0.1$

PERCENTAGE FROM $1-4$

348

428

$23 \%$

5. Firm Size

0.0

0.0

0.0

6. Aging/Management Posts

$-0.6$

$-0.3$

$-0.3$

TOTAL EXPLAINED $(1-6)$

$-2.7$

$-1.8$

$-0.9$

PERCENTAGE FROM 1-6

448

$50 \%$

$35 \%$

Sources: See text.

* Aging/Management Posts estimates for 1975-1981 (and by extension 1975-1986) are extrapolated from the estimates for 1981-1986 based on the rates of labor-force aging in the two sub-periods.

\section{EXHIBIT 3 \\ Distribution of Private Sector Worker and Proportion of Unionized by Firm Size}

Firm Size

1 to 29

30 to 99

100 to 499

500 to 999

Over 1000

\section{Proportion}

$1977 \quad \underline{1985}$

$40.6 \quad 38.8$

$17.9 \quad 18.1$

$16.2 \quad 17.6$

4.8

20.5
Unionization Rate

$\underline{1977} \quad \underline{1985}$

0.6

0.6

9.0

7.5

33.2

57.8

82.9
26.7

47.4

74.8

Sources: Basic Survey of Labor Unions

Labor Force Survey

Japan Statistical Yearbook (Tables on Public Sector Employees) 
Number of Rate of Newly Organized Workers in Japan and U.S.: 1965-1985

Japan

(1) new unions (in 1000's)

\section{United States}

(3)

\# workers

organized by NLRB elections (in 1000's)
(4)

(3) /employ ment, private non-agricul tural

$\begin{array}{rrrrr}1966 & 145 & .49 & 314 & .61 \\ 67 & 150 & .49 & 340 & .58 \\ 68 & 162 & .51 & 261 & .46 \\ 69 & 207 & .65 & 279 & .47 \\ 1970 & 225 & .68 & 301 & .52 \\ 71 & 231 & .68 & 260 & .45 \\ 72 & 163 & .47 & 280 & .46 \\ 73 & 182 & .51 & 216 & .34 \\ 74 & 189 & .53 & 184 & .29 \\ 75 & 165 & .45 & 204 & .33 \\ 76 & 120 & .32 & 156 & .24 \\ 77 & 108 & .29 & 201 & .30 \\ 78 & 87 & .23 & 155 & .22 \\ 79 & 107 & .28 & 191 & .26 \\ 1980 & 93 & .24 & 173 & .23 \\ 81 & 116 & .29 & 144 & .19 \\ 82 & 83 & .20 & .- & . \\ 83 & 87 & .21 & 74 & .10 \\ 84 & 65 & .15 & 90 & .11 \\ 85 & 74 & .17 & 76 & .09 \\ 86 & 60 & .14 & 74 & .09\end{array}$

Source: Japan, Basic Survey of Labor Unions, Labor Force Survey All employees, including government and agriculture but excluding self-employed

U.S., National Labor Relation's Board, annual reports, workers newly organized from RC election cases won by unions.

Nonagricultural employment and government employment from Council of Economic Advisors, Economic Report of the President, 1989, Table B-43 


\section{EXHIBIT 5}

Determinants of union organizing activity and management opposition and their effect on unionization of new workers.

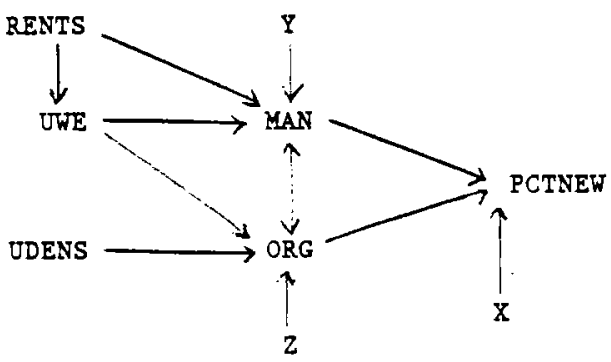

The first relation

Determination of organizing success: PCTNEW = f(MAN, ORG, X) where PCTNEW - number of workers organized/labor force

MAN - resources devoted by management to opposing unions

ORG = resources devoted by unions to organizing

$\mathrm{X}=$ other factors that influence outcome

The second relation

Management opposition: MAN = g(UWE, RENTS, ORG, Y)

where UWE = union wage effect and union effect on working conditions where RENTS - quasi-rents or profits

where $Y$ - other relevant factors, largely relating to product

market factors such as deregulation of industries, etc., which determine effect of unionism on profitability

The third relation

Union and worker organizing effort: ORG $=h$ (UWE, MAN, UDENS, 2 ) where UDENS - union density at the beginning of the period $\mathrm{Z}$ = other relevant factors, largely relating to the labor market 


\section{EXHIBIT 6}

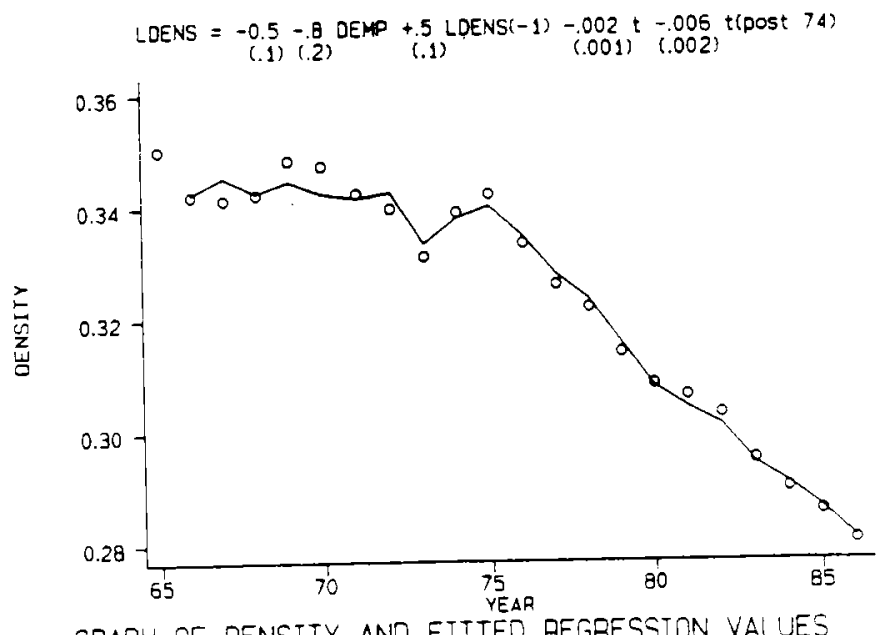

GRAPH OF DENSITY AND FITTED REGRESSION VALUES

$6 A$

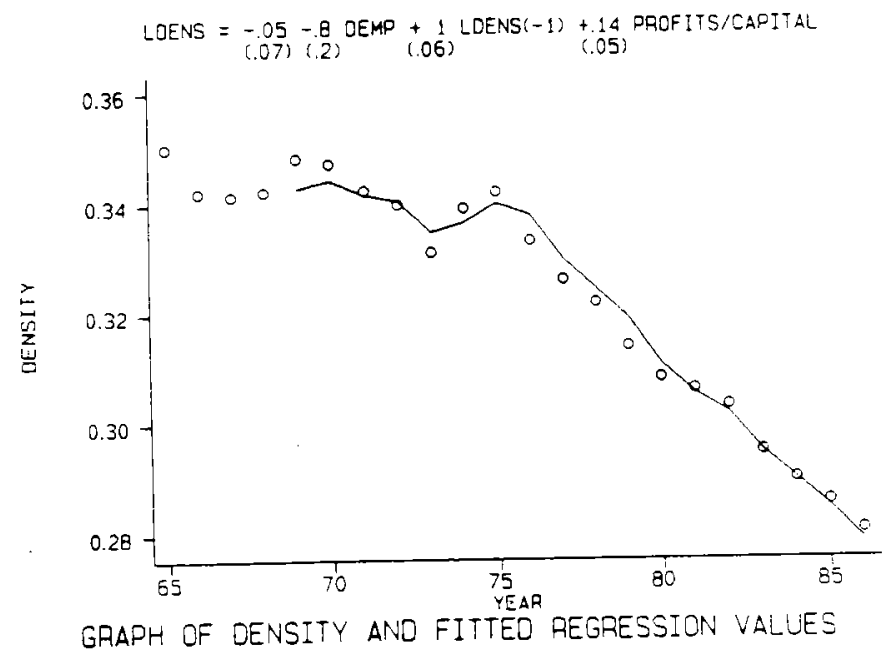

$6 \mathrm{~B}$

LDENS is in density. DEMP is the change in In employees. LDENS(-1) is lagged in density. $t$ and $t$ (post-74) are time trends..

Sources: Density from the Survey of Labor Unions and the Labor Force Survey.

Employees from the Labor Force Survey.

Profits and capital from the Survey of Commercial Enterprises 


\section{EXHIBIT 7}

The Effect of Profits and Value Added on Changes in Union Density And Organizing Rate - Pooled Cross-Section and Time Series: 1966-1986

ALI INDUSTRIES

(1)

$\Delta$ In Employment
Profits/Capital

$\begin{array}{lll}-.83 & -.88 & -.86 \\ (.03) & (.03) & (.03)\end{array}$

In Density $(-1)$

.052

.034

(.009)

(.01)

.029

(.01)
2.4

1.0

$-.18$

3.2

(.02)

(.50)

Time $\times 100$

Post-74 time $\times 100$

Industry dummies

$-7.2$

\section{$-2.4$}

Year dummies

no

no

18

$-.18$

$-.01$

$-3.0$

25

Constant

$-.18$

.68

.74

.76

.37

386

25

no

$-4.1$

.52

$\mathrm{R}^{2}$

N

386
.55

383 a

a) For regressions with year dummies the dependent and independent variables are the deviations from the industry means calculated by regressing all of the variables on the vector of industry dummies. The DDENS dependent variable is the change in In union density where union density is calculated as union members over employees. LPCTNEW is the log of the ratio of members of new unions to employees.

Sources:

The profit variable is the "operating profits or losses" (eigyo soneki) and the capital variable is the "total assets" (shihon) from the Survey of Commercial Enterprises as reported in the Japan Statistical Yearbook. The regressions using these variables include six one-digit industries (mining, construction, manufacturing, transportation and communications, trade and utilities) and 16 two-digit manufacturing industries. Values are converted to calendar year values from fiscal year values using the formula 
$\mathrm{v}($ calendar $)=\mathrm{v}($ fiscal $) \star 2 / 3+\mathrm{v}$ (fiscal $)(-1) \star 1 / 3$. The panel is not balanced as industry coverage varies from year to year, and the years 1967 and 1968 are missing as data is unavailable. (A Statistical Appendix is available from the authors on request.) The variables are deflated using the consumer price index series from Katsuyo Rodo Iokei (Practical Labor Statistics), Tokyo: Japan Productivity Center, 1988, p.39, series no. 13.

The Employees variable is from the Census of Manufacturers for two-digit manufacturing industries and from the Labor Force Survey for one-digit industries outside of manufacturing.

The union members series is from the Survey of Labor Unions, using the series for unit unions (tan'i kumiai). Union density is calculated as union members/ employees.

The members of new unions series is from the Survey of Labor Unions, using the series for "actual new union members" (Jisshitsuteki Shinsetsu Kumiaiin). 


\section{EXHIBIT 8}

The Effect of Profits and Value Added on Changes in Union Density And Organizing Rate - Pooled Cross-Section and Time Series: 1966-1986

\section{MANUFACTURING}
(1)
(2)
(3)
(4)
(3)

\begin{tabular}{|c|c|c|c|c|c|c|}
\hline DEPENDENT VARIABLE & DDENS & DDENS & DDENS & IPCTNEW & IPCTNEW & LPCTNE \\
\hline$\Delta$ ln Employment & $\begin{array}{l}-.92 \\
(.05)\end{array}$ & $\begin{array}{l}-.88 \\
(.05)\end{array}$ & $\begin{array}{l}-.85 \\
(.05)\end{array}$ & & & \\
\hline Profits/Capital & $\begin{array}{l}.045 \\
(.012)\end{array}$ & & & $\begin{array}{l}2.0 \\
(.39)\end{array}$ & - & \\
\hline $\begin{array}{l}\text { In Quasi Rents } \\
\text { per Employee }\end{array}$ & & $\begin{array}{l}.056 \\
(.01)\end{array}$ & $\begin{array}{l}.045 \\
(.01)\end{array}$ & & $\begin{array}{l}.91 \\
(.27)\end{array}$ & $\begin{array}{c}.97 \\
(.35)\end{array}$ \\
\hline In Density $(-1)$ & $\begin{array}{l}-.21 \\
(.02)\end{array}$ & $\begin{array}{l}-.24 \\
(.02)\end{array}$ & $\begin{array}{l}-.20 \\
(.02)\end{array}$ & $\begin{array}{l}.84 \\
(.67)\end{array}$ & $\begin{array}{l}.27 \\
(.54)\end{array}$ & $\begin{array}{l}.39 \\
(.57)\end{array}$ \\
\hline Time / 100 & $\begin{array}{l}-.41 \\
(.1)\end{array}$ & $\begin{array}{l}-.39 \\
(.09)\end{array}$ & & $\begin{array}{l}-6.8 \\
(2.4)\end{array}$ & $\begin{array}{l}-5.4 \\
(2.1)\end{array}$ & \\
\hline Post-74 time / 100 & $\begin{array}{l}.27 \\
(.1)\end{array}$ & $\begin{array}{l}-.04 \\
(.11)\end{array}$ & & $\begin{array}{l}-2.5 \\
(3.4)\end{array}$ & $\begin{array}{l}-10 \\
(2.8)\end{array}$ & \\
\hline Industry dummies & 19 & 19 & 19 & 19 & 19 & 19 \\
\hline Year dummies & no & no & 20 & no & no & 20 \\
\hline Constant & -.18 & -.64 & .03 & -4.5 & -12 & 95 \\
\hline 2 & & & & & & \\
\hline $\mathbf{R}$ & .64 & .55 & .60 & .58 & .55 & .46 \\
\hline N & 283 & 420 & 420 & 281 & 413 & 413 \\
\hline
\end{tabular}

a) For regressions with year dumies the dependent and independent variables are the deviations from the industry means calculated by regressing all of the variables on the vector of industry dummies. The DDENS dependent variable is the change in In union density where union density is calculated as union members over employees. IPCTNEW is the log of the ratio of members of new unions to employees.

Sources :

The Quasi Rents variable is calculated as Value Added - Compensation * Employees and is in Yen (Constant). 
The Value Added variable is from the Census of Manufacturers as reported in the Japan Statistical Yearbook. The variable is for all firm sizes with the post-1980 series for firm size 4 and over spliced to the earlier series. The variable is deflated as for profits. Industry coverage is for manufacturing and 19 two-digit industries within manufacturing. As for profits coverage varies from year to year.

The Compensation variable is from the Monthly Labor Survey for extablishments with more than four regular workers. Deflated by CPI.

Other variables as in Exhibit 7. 


\section{References}

Dickens, W. and Leonard, J. (1985) "Acoounting for the Decline in Union Membership, 1950-1980," Industrial and Labor Relations Review 38:3

Dore, R. (1986) Flexible Rigidities, Stanford: Stanford

Employment occupation General Research Center(1987) Koiki Jinji Kanri to Koyō chōsei ni Kansuru Jittai chōsa Hōkokusho (Survey of Wideranging Personnel Management and Employment Adjustment) Tokyo: Koyo Shokugyō sōgō Kenkyūjo

Farber H. (1987) "The Decline of Unionization in the United States: What can be Learned From Recent Experience?" National Bureau of Economic Research Working Paper No. 2267, Cambridge MA, May

Freeman, R. (1985) "Why are Unions Faring Poorly in NLRB Representation Elections?" in Thomas A. Kichan, ed. "Challenges and choices Facing American Labor, Cambridge MA: MIT, pp. 45-64

(1988) "Contraction and Expansion: The Divergence of Private Sector and Public Sector Unionism in the United States," Journal of Economic Perspectives $2: 2$

, and Medoff, J. (1984) What Do Unions Do? N.Y.: Basic Books

, and Pelletier (1989) "The Impact of Industrial Relations Legislation on Union Density in the United Kingdom and Ireland," National Bureau of Economic Research Working Paper, Cambridge MA,

Garon, S. (1987) The State and Labor in Modern Japan, Berkeley: The University of Califormia Press

Goldfield, M. (1987) The Decline of Organized Labor, Chicago: University of Chicago Press

Gould, w. (1984) Japan's Reshaping of American Labor Law, Cambridge: MIT Press

Japan Central Labor Cormission, Ghüō Rödō Jihō (Central Labor Bulletin), Monthly

Japan Institute of Labor (1986), Japan Labor Bulletin, June, pp.5-8

Japan Labor Problems Research Center, (1988) Rōdō Kumiai no Kasseika to Kore Kara no Kumiai Senryaku ni Kansuru Jittai (The situation on activization of labor unions and union strategies from this point), Tokyo: Kokusai Sangyō Rōdo Kenkȳ̄ Sentā.

Japan Ministry of Labor, Rōdర Kumiai Kihon Chösa (Basic Survey of Labor Unions), Annual

Japan Ministry of Labor (1986), Nihon no Rödō Kumiai no Genjō: Rōdō Kumiai Katsudō nado Jittai chosa Hökoku, (Survey of Labor Union Activity)

Japan Ministry of Labor, Yearbook of Labor Statistics, Annual 
Japan Ministry of Labor Policy Division (1987) Nihonteki Koyo Kankö no Henka to Tenbo (Japanese Employment Practices: Changes and Views)

Japan office of Management and coordination, Japan Statistical Yearbook, Anmual

Japan Office of the Prime Minister, Rodo Ryolu Chosa (Labor Force Survey), Armual

Japan Productivity Center (1988a), Katsuyo Rodo Tokei Nenpo (Practical Handbook of Labor Statistics)

Japan Productivity center (1988b), Hataraku koto no Ishiki, (Attitudes about Work) Tokyo: Japan Productivity Center

Kataoka, N. (1984) Kiro ni Tatsu Rödösha no Ninken (Workers' Rights at the Crossroads), Tokyo: Horitsu Bumkasha

Koike, K. (1988), Understanding Industrial Relations in Modern Japan, Iondon: Macmillan

Nakamura, K. (1986), "Daisanji Sangyō ni okeru Rōdō Kuniai no Kessei to sono koka," (The formation of labor unions in tertiary incustry and their effects), Nihon Rodo Kyolai Zasshi (Journal of the Japan Institute of Labor), 325 (July): $36-50$

, Sato, H., and Kamiya, T. (1988) Rodo kmiai wa Honto ni Yaki ni Tatteiru ka (Do Labor Unions Really Have a Useful Role?) Tokyo: Sögó Rödō Kenkyūjo

OECD (1987) Employment outlook 1987, Paris: OECD

Ohara Institute for Social Research, Hosei University (1985) Nihon Rōdర Nenpan (Iabour Yearbook of Japan), Tokyo: Rödð Junhosha v.55

Ruback, R. and M. Zimmerman, (1984) "Unionization and profitability: Evidence from the Capital Market", Jounal of Political Economy 92 : 1134-57

Salinger, M. (1984) "Tobin's q, Unionization, and the concentration profits Relationship" Rand Journal of Econamics 15: 159-70

Saxonhouse, G. (1979) "Industrial Restructuring in Japan," Jounnal of Japanese Studies 5.2

Shimada, H. (1980) The Japanese Employment System, The Japan Institute 01 Labor

Shirai, T. (1983) "Japanese Labor Unions and Politics," in Contemporary Incustrial Relations in Japan, ed. T. Shirai, Madison: University of Wisconsin

Wallich and Wallich (1976) "Banking and Finance," in H. Rosovsky and H. Patrick eds. Asia's New Giant: How the Japanese Econony Works, pp. $249-316$ 